DOI 10.37882/2223-2982.2021.09-2.08

\title{
МЕТОДЫ И ПРИЕМЫ ОРГАНИЗАЦИИ ПОЗНАВАТЕЛЬНОЙ ДЕЯТЕЛЬНОСТИ СТУДЕНТОВ ГУМАНИТАРНЫХ СПЕЦИАЛЬНОСТЕЙ ПРИ ИЗУЧЕНИИ ИНФОРМАТИКИ
}

\section{METHODS AND TECHNIQUES FOR THE ORGANIZATION OF COGNITIVE ACTIVITY OF STUDENTS OF HUMANITARIAN SPECIALTIES THE STUDY OF INFORMATICS}

I. Dukhovnikova

A. Korol

Summary: The article is devoted to the consideration of the main methods and techniques of working with students of humanitarian specialties in the study of computer science. The aim of the work is the choice of methods and techniques aimed at enhancing the cognitive activity of students. The authors come to the conclusion that the considered methods and techniques are aimed at the emergence of students' interest in the study of the subject «Informatics». Interested students are able to better understand the material, consider the basic concepts, classifications, terms, and skillfully apply them in their educational and research work.

Keywords: methods and techniques, enhancing cognitive activity, students of humanitarian specialties, computer science.
Д исциплина «Информатика» представляет собой молодую, но очень динамично развивающуюся науку. Использование информационных техноправлено на оптимизацию и уменьшение трудозатрат, повышение производительности и эффективности труда. Проблемам развития информатизации в практике школьного и вузовского образования посвящены исследования А.П. Гришаевой (2003), В.Л. Селиванова (2003), Э.Т. Селивановой (2000), В.Н. Тимкина (2000), Е.К. Хеннер (2016), О.Я. Кравец (2012), О.В. Бочкаревой (2021), М.В. Вакуленковой (2008), Н.П. Табачук (2019) и др.

Анализ указанных работ показывает, что специфика контекстного, профессионально ориентированного подхода с использованием информационных технологий в преподавании информатики студентам гуманитарных специальностей многими авторами признается достаточно эффективной.

Как отмечает профессор П.И. Пидкасистый, в процессе преподавания непрофильных дисциплин («Информатика») необходимо осуществлять организацию ауди-

\section{Духовникова Ирина Юрьевна}

старший преподаватель, ФГБОУВО "Тихоокеанский государственный университет", г. Хабаровск

009657@pnu.edu.ru

Король Александр Михайлович

к.n.н., профессор, ФГБОУВО "ТИхоокеанский государственный университет", г. Хабаровск

kor_kor2001@mail.ru

Аннотация: Статья посвящена рассмотрению основных методов и приемов работы со студентами гуманитарных специальностей при изучении информатики. Целью работы является выбор методов и приемов, направленных на активизацию познавательной деятельности студентов. Авторы приходят к выводу, что рассмотренные методы и приемы направлены на возникновение интереса обучающихся к изучению предмета «Информатика». Заинтересованные студенты способны глубже понять материал, рассмотреть основные понятия, классификации, термины, а также умело применить их в своей учебной и исследовательской работе.

Ключевые слова: методы и приемы, активизация познавательной деятельности, студенты гуманитарных специальностей, информатика.

торной и самостоятельной работы студентов не только с учетом традиций научно-педагогической школы, но и в контексте профессиональной деятельности студентов, направленной на развитие познавательной активности: активные и интерактивные методы и приемы обучения $[4$, c. 76$]$.

Актуальность работы обусловлена необходимостью изучения современных методов и приемов организации деятельности студентов гуманитарных специальностей при изучении курса «Информатика». Актуальность работы также подтверждается количеством употребления терминов «информационные технологии» и «информационные системы» в федеральном законе «Об образовании в Российской Федерации» - 175 словосочетаний [5].

Целью данной работы является разработка методов и приемов организации познавательной деятельности студентов на материале учебного пособия «Информатика», составленного Е.Н. Гусевой и коллективом авторов [1].

Научной новизной работы является адаптация мето- 
дов и приемов обучения информатике студентов гуманитарных специальностей, направленных на создание интереса к изучению непрофильного предмета.

Практическая ценность данной статьи заключается в том, что указанные методы и приемы могут быть использованы при разработке курса «Информатика» для студентов гуманитарных специальностей.

Обратимся к классификации методов обучения. Известны 3 традиционных классификации методов обучения: 1) на основании источника знаний (П.И. Пидкасистый); 2) по назначению (М.А. Данилов, Б.П. Есипов); 3) по дидактическим целям (Г.И. Щукина, И.Т. Огородникова).
Согласно классификации И.Я. Лернера и М.Н. Скаткина, методы обучения разделяются по типу познавательной активности: 1) объяснительно-иллюстративный (информационно-рецептивный); 2) репродуктивный; 3) проблемное изложение; 4) частично-поисковый (эвристический); 5) исследовательский [2, с. 117-120]. Интерес представляет классификация, предложенная Ю.К.Бабанским, посвященная реализации учебно-познавательного процесса: 1) методы организации и осуществления учебно-познавательной деятельности; 2) методы стимулирования и мотивации учебно-познавательной деятельности; 3) методы контроля и самоконтроля за эффективностью учебно-познавательной деятельности [3, с. 165]. Реализация методов активизации познаватель-

Методы активизации познавательной деятельности обучающихся гуманитарных

Таблица 1. специальностей при изучении информатики

\begin{tabular}{|c|c|c|}
\hline Название метода & $\begin{array}{c}\text { Способ активизации познава- } \\
\text { тельной } \\
\text { деятельности }\end{array}$ & Реализация метода при изучении информатики \\
\hline $\begin{array}{l}\text { Наглядный метод осуществления } \\
\text { познавательной деятельности }\end{array}$ & Плакат «с белыми пятнами» & $\begin{array}{l}\text { Студентам предлагается в форме дискуссии обсудить схему заполнения } \\
\text { «Системы передачи данных», доработать пример составления таблицы } \\
\text { истинности, особенности внутренней и внешней памяти компьютера и др. }\end{array}$ \\
\hline $\begin{array}{l}\text { Словесный метод осуществления } \\
\text { познавательной деятельности }\end{array}$ & «Лекция с ошибками» & $\begin{array}{l}\text { Студентам предлагается найти и исправить в устной речи преподавателя } \\
\text { ошибки в ходе чтения лекции. Студенты гуманитарных специальностей, } \\
\text { ориентированные на тип профессии «человек-человек», будут осознанно } \\
\text { исправлять ошибки, сознательно допущенные преподавателем по темам } \\
\text { лекций, посвящённых архитектуре компьютера (например, устройство } \\
\text { ввода и вывода информации, внешняя память). }\end{array}$ \\
\hline $\begin{array}{l}\text { Проблемно-поисковый метод } \\
\text { организации познавательной } \\
\text { деятельности }\end{array}$ & Проблемная лекция & $\begin{array}{l}\text { Лекция начинается с постановки проблемы: «Выбор оптимальной } \\
\text { операционной системы для решения задач пользователей гуманитарных } \\
\text { специальностей». Знакомство с известными операционными системами и } \\
\text { их особенностями. Решение - выбор оптимальной операционной системы } \\
\text { каждым студентом и аргументация своей точки зрения. }\end{array}$ \\
\hline $\begin{array}{l}\text { Проблемно-поисковый метод } \\
\text { организации познавательной } \\
\text { деятельности }\end{array}$ & Учебная дискуссия & $\begin{array}{l}\text { Студентам предлагается обсудить «Виды мошенничества в социальных се- } \\
\text { тях». Организация работы в сети «Интернет», разработка правил, доступное } \\
\text { обучение граждан пенсионного возраста. }\end{array}$ \\
\hline $\begin{array}{l}\text { Метод стимулирования и мотивации } \\
\text { интереса к обучению }\end{array}$ & Эвристическая беседа & $\begin{array}{l}\text { Обсуждение запоминающих устройств, внутренней памяти и внешних } \\
\text { запоминающих устройств. Студенты приходят к выводу, каким запоми- } \\
\text { нающим устройствам они отдают предпочтение, находят для себя новые } \\
\text { способы хранения информации. }\end{array}$ \\
\hline Исследовательский метод & $\begin{array}{l}\text { Составление памятки «Защита } \\
\text { информации в сети» }\end{array}$ & $\begin{array}{l}\text { Студентам предлагается самостоятельно изучить методы защиты информа- } \\
\text { ции в сети Интернет, а также разработать план по защите от опасностей при } \\
\text { работе в сети. }\end{array}$ \\
\hline $\begin{array}{l}\text { Словесный метод активизации } \\
\text { познавательной деятельности }\end{array}$ & $\begin{array}{l}\text { Написание мини-сочинений } \\
\text { с действующим алгоритмом } \\
\text { действий. }\end{array}$ & $\begin{array}{l}\text { Примерные темы составления алгоритмов: } \\
\text { 1. Расскажи бабушке о поиске в Интернете рецептов засолки огурцов. } \\
\text { 2. Научи дедушку пользоваться электронной почтой. 3. Расскажи знакомым } \\
\text { родителям о том, как контролировать сетевой трафик на компьютере } \\
\text { подростка. }\end{array}$ \\
\hline $\begin{array}{l}\text { Методы контроля и самоконтроля за } \\
\text { эффективностью учебно-познаватель- } \\
\text { ной деятельностью }\end{array}$ & КВН, конференции, викторины & $\begin{array}{l}\text { Подобные форматы работ создаются с целью закрепления нового } \\
\text { материала. Примерные темы: «Компьютерные сети», «Сетевые сервисы и } \\
\text { стандарты», др. }\end{array}$ \\
\hline
\end{tabular}


Приемы активизации познавательной деятельности обучающихся гуманитарных специальностей при изучении информатики

\begin{tabular}{|c|c|}
\hline Название приема активиз & Пример реализации при изучении информатики \\
\hline \multicolumn{2}{|c|}{ Приемы, активизирующие интерес студентов кпредмету на этапе восприятия } \\
\hline Прием новизны & $\begin{array}{l}\text { На вводном занятии можно рассказать студентам интересные факты из истории по- } \\
\text { явления информатики, особенностях информационных революций. }\end{array}$ \\
\hline Прием семантизации & $\begin{array}{l}\text { Объяснение терминов и понятий простым и доступным языком, интересным студен- } \\
\text { там. } \\
\text { «Атрибутивные свойства информации - это свойства, без которых информация не } \\
\text { смогла бы существовать» }[1, \text { с. } 12] .\end{array}$ \\
\hline Прием динамичности & Рассмотрение свойств информации в динамике и развитии. \\
\hline Прием значимости & $\begin{array}{l}\text { Важность информации в жизни человека, внешних и внутренних носителей информа- } \\
\text { ции и др. }\end{array}$ \\
\hline \multicolumn{2}{|c|}{ Приемы, активизирующие интерес к обучению на этапе усвоения материала } \\
\hline Эвристический метод & $\begin{array}{l}\text { Студентам задаются трудные вопросы при изучении сложных тем: «Создание сайтов», } \\
\text { «Логические операции и функции». }\end{array}$ \\
\hline Исследовательский прием & $\begin{array}{l}\text { Студенты на основе самостоятельно полученных знаний могут сами сформулировать } \\
\text { выводы. Примерные темы: «Виды моделирования», «Парадигмы программирова- } \\
\text { ния». }\end{array}$ \\
\hline
\end{tabular}

ной деятельности обучающихся гуманитарных специальностей представлена в таблице 1.

При рассмотрении классификации методов активизации познавательной деятельности студентов, мы ориентировались на возможность проявления способов реализации методов на учебном предмете «Информатика». Целью применения данных методов и способов их реализации является способность заинтересовать студентов гуманитарных специальностей, ориентированных на тип профессий человек-человек, предметом технической специальности «Информатика».

Рассмотрим приемы, способствующие организации познавательной деятельности студентов, представленные в таблице 2.

Таким образом, при рассмотрении основных методов и приемов, способствующих активизации познавательной деятельности студентов гуманитарных специальностей при изучении информатики мы пришли к следующим выводам:

1. Обучающихся непрофильных специальностей необходимо заинтересовать в изучении предмета с помощью методов и приемов, активно применяемых на профильных предметах: исследовательская работа, написание мини-сочинений, игровые методики, приемы новизны, семантизации и значимости.

2. Заинтересованные студенты гуманитарных специальностей могут глубже рассматривать основные цели, задачи и особенности предмета, с разных сторон подойти к рассмотрению семантики определений, тем самым углубить свои знания об информатике.

\section{ЛИТЕРАТУРА}

1. Гусева Е.Н. Информатика: учебное пособие / Е.Н. Гусева, И.Ю. Ефимова, Р.И. Коробков, И.Н. Мовчан, Л.А. Савельева. М.: ФЛИНТА, 2016.260 с.

2. Лернер И.Я. 0 методах обучения / И.Я. Лернер, М.Н. Скаткин// Советская педагогика. 1965. № 3. С. 115-128.

3. Педагогика/ Под ред. Ю.К. Бабанского. М.: Просвещение, 1988. 479 с.

4. Пидкасистый П.И. Организация учебно-познавательной деятельности студентов. М.: Педагогическое общество, 2005. 144 с.

5. Федеральный закон № 273-Ф3 «06 образовании в Российской Федерации» (с изменениями на 2021 год). [Электронный ресурс]. URL: https://zakonobobrazovanii.ru/skachat-zakon-ob-obrazovanii (дата обращения: 30.07.2021).

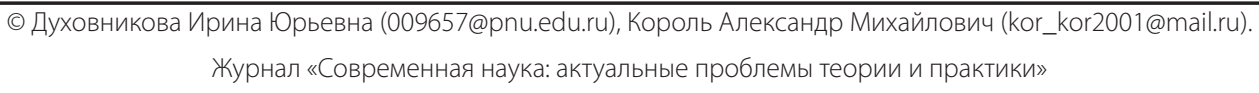

